\title{
A Brief Study on Green Technology Innovation of China's Coal Enterprises
}

\author{
Hao Xiaomeng* and Lei Ping \\ School of Humanities and Economic Management, China University of Geosciences, Beijing, China
}

\begin{abstract}
Tradeoffs between economy, safety and environmental protection have become a great concern for China's coal enterprises since long time ago. One promising solution is the green technology innovation in the coal enterprises. The problems existing in China's coal enterprises are briefly introduced at first, and then the following steps are proposed to fully develop the green technology innovation system. Firstly, the concept of green technology innovation is introduced. Secondly, education of sustainable development should be promoted. Thirdly, organization systems that are compatible with the green technology innovation should be built. Last but not least, green technology innovation should be a target for development strategies of the enterprise.
\end{abstract}

Keywords: Coal enterprises, development strategies, green technology innovation.

\section{INTRODUCTION}

By virtue of unique geographic advantage, China has abundant coal resource. Coal is the safest, and the most economic and reliable resource in China. Our energy resources are characterized by rich coal, lack of petroleum, and deficiency in gas, determining the important role of coal as the primary energy. As presented in Potential Assessment of Nationwide Coal Resources Status from Ministry of Land and Resources, the total coal resource in China is 5.9 trillion tons, wherein the predictable resource is up to 3.88 trillion tons. According to Peoples Network reported, it has been proved that there are 1 trillion tons of reserves in China, taking up $11 \%$ of world's total stores. Ever since the foundation of new China, coal has occupied more than $70 \%$ of the production and consumption of primary energy in China.

China is at the stage of a developing country. Though a number of new energies were found gradually, coal still accounts for a considerable percentage in energy consumption, and it will still play a significant role in the main energy for many more years. To coincide with the development of new energy, coal is replaced by new energy to certain extent. It is one of the reasons why the growth rate of coal consumption demonstrates a downward trend. The increase rate of overall coal consumption dropped from $12.63 \%$ in 2005 to $2.73 \%$ in year 2013. Despite the rebounded growth rate in certain years, generally, it is declining. More details are shown in the Fig. (1) below.

The growth rate of total coal consumption shows a decreasing trend: on the basis of the percentage of coal in the construction of energy production and consumption, take year 2013 as an example, (Fig. 2) and the growth rate of total coal consumption is in a downside; on the basis of the

*Address correspondence to this author at the School of Humanities and Economic Management, China University of Geosciences, Beijing, China; Tel: 18986139113; E-mail: Hunter2011@foxmail.com

$1876-973 X / 15$ proportion of resources status and coal in the construction of energy production and consumption, take year 2013 as an example. Figs. ( $2 \& 3)$ display the condition of major energy consumption and primary energy production in 2013 respectively. We can learn from the figures that the amount of coal consumption and the amount of coal production is $66 \%$ and $76 \%$ respectively, which are well higher than the collective amount of production and consumption in regards of petroleum, natural gas, hydroelectricity and nuclear power. In consequence, coal will still be the dominating energy in production and consumption over a period of time [1-3].

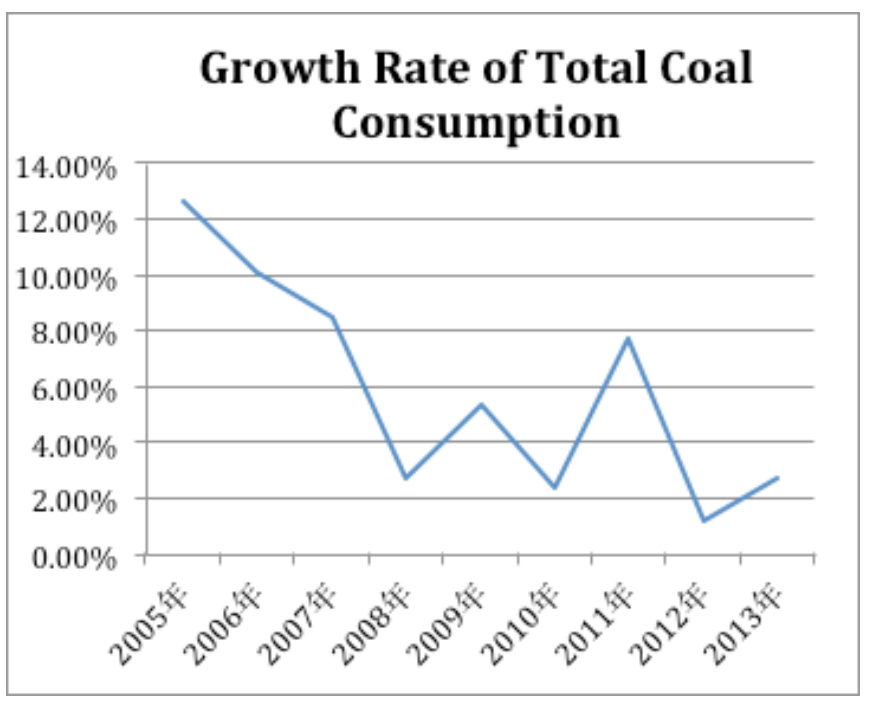

Fig. (1). Growth rate of Total Coal Consumption. Data resource: website of national bureau of statistics.

We can conclude from the above that coal-oriented energy construction in $21^{\text {st }}$ century will not be changed in a fairly long period, and the crucial position of the coal 
industry in the development of national economy and society will stay the same. Especially in northern regions, such as Shanxi, Shaanxi province, etc., coal is the indispensable living resource, and people there depend on coal for survival. Coal is not only the source of income but also provides more employment opportunities for the society.

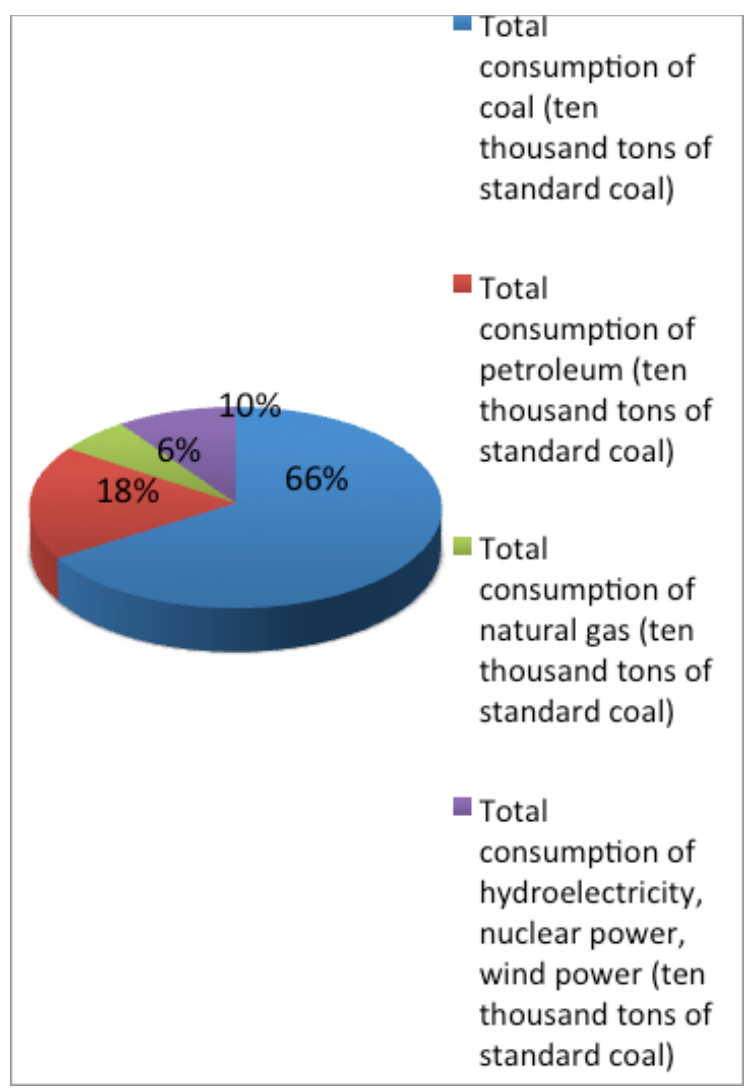

Fig. (2). Condition of Major Energy Consumption in 2013. Data resource: website of national bureau of statistics.

Coal is the pillar industry in China. Nonetheless, for the coal industry in China, the whole technical level is not satisfactory. The equipment is under-developed and workers' safety awareness in this industry is relatively low, which results in a series of problems and high frequency of production accidents in coal mining. In recent years, the increased enforcement of safety regulations in China has solved the safety issues to some degree. As indicated in Fig. (4), starting from 1998, the death toll for producing one million tons of coal has been coming down year by year. Yet, the death toll in 2011 in China was still 10 times as much as in America, as manifested in China News Net. Security production in the coal industry remains the urgent question needed to be solved.

In comparison with some high-quality clean energy, application of the coal resource will inevitably cause environmental pollution. Among the prime pollutants, $90 \%$ of sulfur dioxide, $75 \%$ of oxynitride and $60 \%$ of suspended particulate matter are emitted from coal. In reference to the report from Sohu Economy, the primary consumption resource in 2012 was 36.2 trillion tons of coal, occupying $20 \%$ of the world energy; energy consumption per GDP

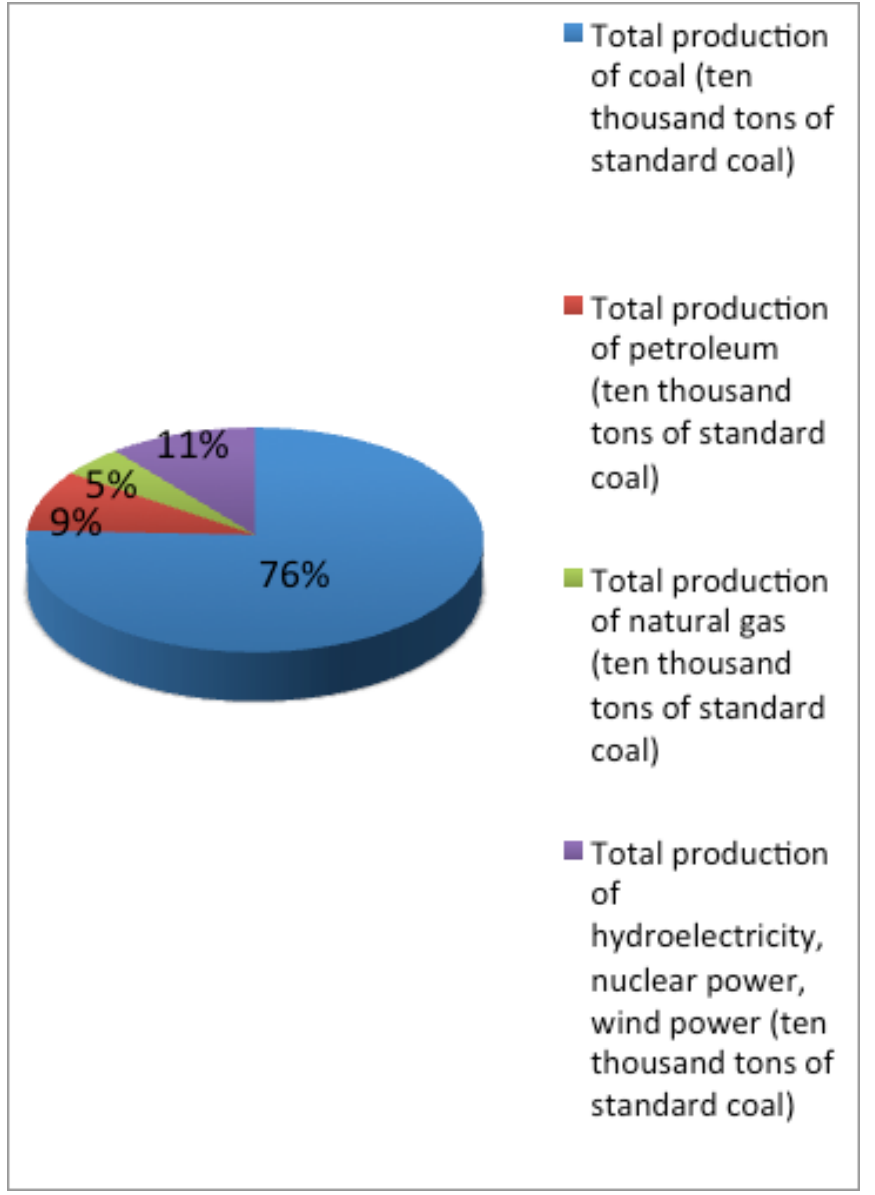

Fig.(3). Condition of Major Energy Production in 2003. Data resource: website of national bureau of statistics.

\section{Death Toll of Producing One Million Tons}

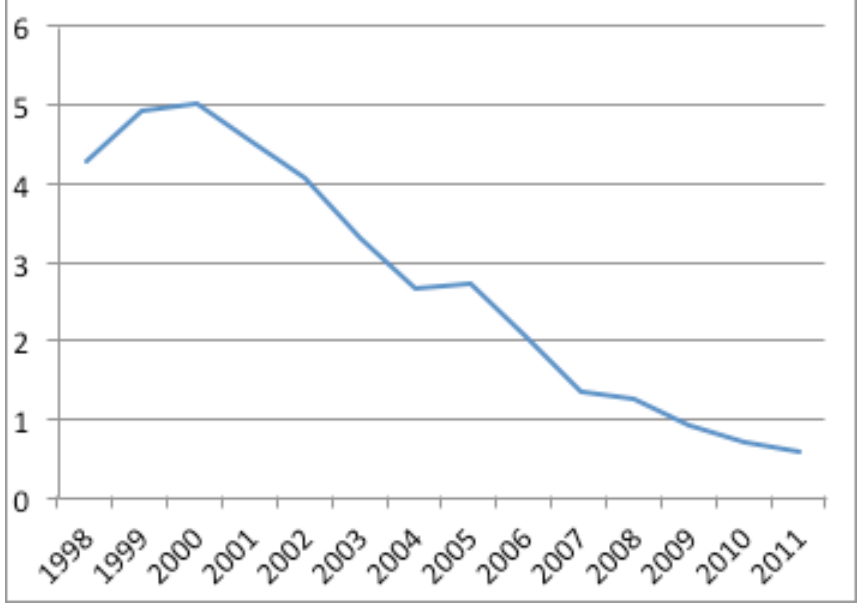

Fig. (4). Death toll for producing one million tons of coal all over China (person). Data resource: China year book of safety production.

is 2.5 times as much as the world's average, 3.3 times as much as American GDP and 7 times as much as Japanese GDP. Meanwhile, the death toll is higher than that the developing countries such as Brazil, Mexico and so on. On the grounds of the extensive consumption of energy in China 
(particularly coal), people have to pay special attention to the severe environmental pollution. For example, people nowadays attach great importance to the hazy weather. How can energy development coordinate with environmental protection? It has become a serious question for the Chinese to consider economic and environmental friendliness.

The coal industry in China is confronting with the questions of how to balance economy, safety and environmental protection. The traditional concept of unilateral development goes after economic interest, abuses technology, squanders resources and destroys environment. Today, we are supposed to consider the benefit of the coal industry and safety production, and reduce the environmental disruption to the minimum level. We can only achieve this by implementing the strategy of green technology innovation.

\section{GREEN TECHNOLOGY INNOVATION IS THE APPROACH TO SOLVE PROBLEMS AROUSED FROM COAL INDUSTRY}

$\mathrm{J} \bullet \mathrm{A} \bullet$ Schumpeter, Austrian-American economist, first proposed an innovative idea, believing that innovation is the essence of economic development in Theory of Economic Development in 1912. Later on, technology innovation was accepted by numerous scholars and contributed greatly to the advancement of economy and human society.

Since mid-1910s, questions such as energy crisis, sharp decline in forest resource, destruction of ecological balance, acid rain, etc. have been posting a serious threat to human survival and development. Environmental problem has increasingly drawn the attention from countries worldwide. In 1992, the concept of sustainable development was put forward during United Nations Conference on Environment and Development (UNCED). With the continuous enhancement of understanding of this concept, the "green" storm swept all over the world. "Green technology" in the scientific field was born at the right moment. "Green development" has evolved from pure economic noun to a basic consensus of human's life development. Therefore, green development has drawn widespread attention.

Green technology is the generic term and refers to processes, crafts and products that abide by the ecological principles and rules of ecological economy to save resources, and avoid, eradicate or relieve ecological environmental pollution and destruction with fewest least ecological negative effects and no or low public hazard. Green technology innovation is collectively known as administration innovation and technology innovation aiming to protect the environment. There are two ways to define such innovation, one is characterized by green technology innovation, and main features are summarized to conclude the definition; the other is to take the production process into account and systematically describe the process of green technology innovation [4].

Green technology innovation in the coal industry is to establish "green coal" based on circular economy, comprehensively exploit coal, underground water, and gas in the mineral area, prevent or reduce unfavorable mining impacts upon the environment as far as possible, reduce pollution, exploit moderately, be cautious in mining, and obtain abundant recovery. To guarantee life safety is the precondition of all mining activities, and to ensure reasonable recovery of resources is the fundamental requirement for exploitation of all resources. Biotransformation of coal and make use of the transformation of fungi, bacteria and other microorganisms to dissolve, liquefy and gasify coal, to enable coal to be transformed into material that is soluble in water or hydrocarbon gas. Then chemicals with distinctive value, clean fuel, industry additives and crop growth promoter, etc. can be extracted from it. In this way, dissolution, liquidation, and gasification of coal will be achieved finally. Newly developed coal gasification, in combination with fuel cells technology, can improve the coal utilization while dramatically reducing environmental pollution. In addition, the recent increased popularization and application of the cleanly mining technology and the coal preparation technology remarkably upgrade the coal quality and reduce pollution. Coal industry in China is suffered from the most severe gas disaster due to the low gas extraction rate, insufficient gas extraction equipment, and impossibility of gathering gas after extraction. The average gas extraction rate is not more than $30 \%$ and part of coal enterprises are still subjected to gas disasters. Gas disasters remain the "number one killer of coal accidents" and one of the critical reasons is the low integrated utilization level of gas in coal industry. In recent years, making electricity from gas has been making rapid progress. If we can take advantage of gas, it will be conducive to the safety production of coal enterprises and also produce positive returns.

By means of green technology innovation, multipurpose use of waste produced by coal enterprises will be achieved, and pollutant emission may well be decreased. It can also protect the environment and generate economic benefits at the same time. One convincing example is that coal ash is utilized as fertilizer and filler materials for high polymer, and coal gangue is processed into heavy chemicals such as crystalline aluminium chloride.

\section{MEASURES OF GREEN TECHNOLOGY INNO- VATION IMPLEMENTED BY COAL ENTERPRISES.}

Many environmental issues such as greenhouse gases, haze, and destruction of the ecological environment appear with the accelerated development of economy and society. With the advent of these issues, the demand of environmental protection is becoming more and more intensive. Employees in the coal enterprises, however, are short of "green" awareness, and "green" value is not widely recognized. To make the matter worse, "green value" is not among the common values of the enterprise. As far as the company is concerned, the cost of running green business in the initial phrase is rather high. But in the long run, green business will integrate economic efficiency and environmental friendliness together, and green technology will be able to lower the expansion of resources and reach the target of cost saving. At the meantime, with the improvement of environmental awareness, citizens are inclined to purchase green products, which will further raise the economic benefit of a company. Hence, staff's awareness of "green" has a direct impact on the long-term progress of a company. 
A large proportion of coal enterprises does not set up administrative organizations for green technology innovation, which will confine the management of the environment. Some companies have established associated departments of green technology innovation and environmental policies. Nevertheless, such environmental departments have no real power, and mostly subordinate to other departments. Personnel in the departments are responsible for multiple tasks and have no specific measures in connection with environmental protection. The formulation of these policies is only to cope with checks from relevant departments so as to pay fewer penalties. Lack of funding and corresponding talents in some companies will greatly restrict capabilities pertinent to green technology innovation. Coal enterprises are supposed to create sectors related to green technology innovation, lay down policies and measures in detail, specify responsibilities of personnel involved and specially designated to the job. Empower to environmental authorities and mobilize the initiative of staff in the department. Moreover, emphasis should be laid on the introduction, cultivation and use of associated talents.

The interior dynamic of corporate green technology innovation mainly comes from multiple aspects such as the need for the economic goal and the environmental consciousness of an entrepreneur. The impetus driving the company to develop green technology innovation is benefit. Propulsion from interest and the national policy of facilitating corporate green technology innovation will bring along substantial gains. It will definitely stimulate the virtuous circulation of the green technology innovation within the enterprises. Strengthening environmental education inside the company will steadily enhance the employees' quality. Continuously improvement of staff's awareness of "green" and entrepreneur's awareness of the environment will contribute to revitalizing the enterprise green technology innovation.

In a short run, the cost benefit of coal enterprises that carry out green technology innovation will be lower than the interest produced by standard technology. If simply depending on the pure technique and market to increase the company's sales volume, it will be painfully slow. Thus, the advancement of corporate green technology innovation demands the energetic support from state policies, considering whether the internal or external factors. First and foremost, it is supposed that a green technology development center shall be established at the national level and the advanced foreign technology shall be selectively absorbed. Meanwhile, the creation of green technology innovation and expansion of service centers to small and medium-sized businesses, combination of the function of consultation, service and intermediary agents, and even venture investment should be based on characteristics of exterior economy, socialization and multidisciplinary approach of innovation and expansion. Furthermore, build an efficient technical information network and an information transmission mechanism whenever possible. Keep abreast of the latest development both at home and abroad, decrease cost of innovation study, and accelerate the progress of green technology innovation in China. Besides, establish policy system and legal system for environment, fiscal, taxation and finance, etc. that can be fitted into the operation of the market mechanism, and create beneficial outer environment for enterprise green technology innovation. What's more, our country is supposed to adopt a preferential policy to green technology innovation on taxation, financing, credit, government procurement, etc., and work out laws and regulations and management policies that can impel green technology innovation. Corporate green technology innovation will be promoted accordingly by policy guidance, constraints from laws and regulations, institutional management, etc.

\section{CONFLICT OF INTEREST}

The authors confirm that this article content has no conflict of interest.

\section{ACKNOWLEDGEMENTS}

Declared none.

\section{REFERENCES}

[1] Pan, P.; Keqiang, W. On Green Technology Innovation of Coal Enterprises in China. J. Wuhan Univ. Technol.,2010, 2, 53-55.

[2] Tingting C. The Existing problems and countermeasures of coal enterprise in environmental management in practice. Resour. Econ. Environ. Protect.,2015, 1, 143.

[3] Xu W.; Qin Shusheng. The exploration of corporate green technology innovation drive green development. Technoecon Manage. Res., 2014, 8, 26-29.

[4] Wang, J.; Wang Z. A brief analysis on green management of coal enterprises. Energy Technol. Manage.,2005, 4, 85-87

(C) Xiaomeng and Ping; Licensee Bentham Open.

This is an open access article licensed under the terms of the Creative Commons Attribution Non-Commercial License (http:// creativecommons.org/licenses/by-nc/4.0/) which permits unrestricted, non-commercial use, distribution and reproduction in any medium, provided the work is properly cited. 